Journal of Yaşar University

http://journal .yasar.edu.tr

Journal of Yasar University 2014 9(33) 5597-5622

\title{
EVALUATION OF WORLD COUNTRIES IN TERMS OF TOURISM INDICATORS THROUGH MULTIVARIATE ANALYSIS METHOD
}

\section{ÇOK DEĞiŞKENLi ANALIZ YÖNTEMIYLE TURIZM GÖSTERGELERi AÇISINDAN DÜNYA ÜLKELERININ INCELENMESI}

\author{
Oktay Emir ${ }^{1}$ \\ Ibrahim Kılıç ${ }^{2}$
}

\begin{abstract}
In the studies that compare countries in terms of tourism indicators, countries are usually evaluated with reference to only one indicator. However, in this evaluation, two important factors such as their population and economic size are usually ignored. Moreover, a standardization which is comprised by different units of measurement (number, time, ratio, etc.) is not applied. This situation causes countries to be wrongly compared in terms of tourism statistics. In this study, it is aimed to rank and classify 47 countries that have examples from almost every region in the world in terms of 9 indicators containing the tourism data between 2004 and 2009 by using multivariate statistical methods. Principal component analysis has been used in order to create the tourism development index for ranking the countries, cluster analysis for classifying, and multidimensional scaling analysis for their place in two-dimensional space. The findings of both standardized and non-standardized data have been provided in order them to be compared. According to the "the tourism development index", the first 3 countries for non-standardized data is USA, France and Spain; nevertheless, this ranking has changed as USA, Egypt and Jamaica for standardized data. On the other hand, it has been observed that the countries have clustered in the best two groups in terms of similarity and/or difference levels for both data sets.
\end{abstract}

Key words: Tourism indicators, tourism development index, tourism statistics, multivariate analysis

\footnotetext{
${ }^{1}$ Anadolu University, Faculty of Business Administration, Department of Hospitality Management, TR-26460Eskişehir, Turkey. E-mail: oktayemir@anadolu.edu.tr

${ }^{2}$ Afyon Kocatepe University, Department of Biostatistics, TR-03200-Afyonkarahisar, Turkey. E-mail:

ibrahimkilic@aku.edu.tr
} 


\section{ÖZET}

Ülkelerin turizm göstergeleri bakımından karşılaştırılmasına yönelik yapılan çalışmalarda genellikle ülkelerin nüfus ve ekonomik büyüklüğü gibi önemli bir faktör göz ardı edilerek tek değişkene göre değerlendirme yapılmakta ve farklı ölçü birimlerinden (sayı, zaman, oran vb) oluşan değişkenler için standartlaştırma yapılmamaktadır. Bu durum, turizm istatistikleri açısından ülkelerin hatalı bir şekilde karşılaştırılmasına neden olmaktadır. Bu çalışmada, çok değişkenli istatistiksel yöntemler kullanılarak dünyanın hemen her bölgesinden örneklerin yer aldığı toplam 47 ülkenin, 2004-2009 yılları arasındaki turizm verilerini içeren dokuz gösterge bakımından sıralanması ve sınıflandırılması amaçlanmıştır. Ülkelerin sıralanmasına yönelik turizm gelişmişlik endeksinin oluşturulmasında temel bileşenler analizi kullanıımış olup, sınıflama yapmak için kümeleme analizi, iki boyutlu uzaydaki konumu için ise çok boyutlu ölçekleme analizi uygulanmıştır. Araştırmada hem standartlaştırılmamış hem de standartlaştırılmış veriler için elde edilen bulgular karşılaştırma yapılabilmesi için birlikte sunulmuştur. "turizm gelişmişlik indeks"ine göre standartlaştırılmamış veriler için ilk 3 sırada Amerika Birleşik Devletleri, Fransa ve İspanya yer alırken, standart veriler için bu sıralamanın Amerika Birleşik Devletleri, Mısır ve Jamaika şeklinde değiştiği tespit edilmiştir. Diğer taraftan, her iki veri seti için benzerlik ve/veya farklılık düzeylerine göre ülkelerin en iyi iki grupta toplandığı tespit edilmiştir.

Anahtar Kelimeler: Turizm göstergeleri, turizm gelişim endeksi, turizm istatistikleri, çok değiş̧enli analiz 


\section{INTRODUCTION}

Increases in income, development of transportation facilities, decreases in transportation prices and the desire to get away from work pressure have resulted in important developments within the tourism sector. This development plays an important role in making the tourism sector an important source of income all over the world. It is expanding rapidly every year and also influences the environment. This is particularly noticeable at certain times of the year, when participation of tourism activities is seen within rapidly growing industrial communities. Therefore, it shows the impact of this sector on the competition process which is experienced by both national and international frames.

Tourism as an industry is made up of non-profitable tourism organizations, tourism marketing facilities, transportation, accommodation, food and beverage services, tourist retail shops and other tourism related activities. Additionally, it is seen as a large and multi-dimensional macro system comprising economic, natural, social, political and technological components (Olalı, 1990). According to the social structure of economic and natural resources, tourism can be evaluated as a method for development, therefore making it more economical than other developmental methods. It carries less danger, does not require much technology and gives results within short periods (Rızaoğlu, 2004).

Tourism contributes to many fields such as national revenue, investment, taxing, foreign currency, employment, infrastructure, education, social and cultural relations, national integration and balanced regional development (Erdmann, 1997; Raina and Agarwal, 2004; Halseth and Meiklejohn, 2009). The contribution through tourism helps influence each country to apply various strategies in order to attract visitors. While some countries focus on natural and historical facilities, some prefer to develop their infrastructure toward the hosting of entertainment facilities, (i.e., concerts, sports events, congress and commercial performance etc.) (Hodur and Leistritz, 2007; Yang et al., 2009).

By attracting more tourists and by providing more economic input, countries have strategically aspired to take place near the top in terms of tourism through using their potential and activities in 
the competition environment. Therefore, they aimed to take place at the top of ranking both in academic studies and common or independent researches.

\section{LITERATURE REVIEW}

Developing countries tend to turn toward tourism revenue for financial development as their ability to compete against more affluent countries is limited. They are unlikely to be able to compete against already developed countries with regard to exporting agricultural and industrial products on international levels (İ̧̧̋̈z and Kozak, 2002; Rosentraub and Joo, 2009).

For this reason, tourism has become an indispensable part of the economic development strategy of developing countries for over half a century (Torres and Momsen, 2004; Scheyvens and Momsen, 2008; Chen and Chiou-Wei, 2009). With increasing demand, developing countries consider tourism as an important sector to be developed in order to pass over the foreign exchange bottle-neck. This is because tourism services are consumed where they are produced, therefore monies paid for tourism products and services generate a reciprocal flow of foreign exchange increase/decrease (Kar et al., 2004; Belloumi, 2010).

It is a well-known fact that tourism can have a different social and environmental effect upon a destination. It has the potential to create an economic impact in relation to tourist expenditure. (Dwyer and Forsyth, 1997). In addition to the economic, social and environmental impact on most countries, tourism is also an indispensable element to small island economies where there is dense tourism activity. According to Schubert et al. (2011), small tropical islands are creating economical strategies regarding construction and financial services relating to the development of mass tourism. This is in preference to their traditional and important export items such as sugar and bananas etc,. These countries endeavor to use tourism as a tool for development. Reasons for this is that they face limitations such as small market size, export concentration, distance and high transportation costs. With proven economic results worldwide, international tourism carries an important quality of economic activity and takes third place in the world for income after the chemical and automotive industries (içcöz and Kozak, 2002). 
According to the World Tourism Organization (WTO, 2010), in 2009 the number of international tourist arrivals reached 880 million people with international tourism receipts reaching 886 billion US dollars.

If the number of tourists in the world in 1950 is taken as 25.3 million, then it can be seen that tourism activities have increased 35 times. It is projected that these numbers will reach nearly 1.6 billion people and two thousand billion \$ in 2020, then in 2050 will be two billion people and 2.1 thousand billion \$ (WTO, 2001). According to 2020 projections (WTO, 2001), it is thought that destinations already at saturation point will show slower development, while other regions will have a faster growth rate. Likewise, it is also projected that Europe will take the lead in total visitor numbers of 717 million, East Asia and the Pacific region will take second place with 397 million and America will take third place with 282 million visitors. It is projected that Africa, the Middle East and South Asia will follow these regions. Hence, it would be wise to believe that Tourism is very important to the economies of many countries. The slowdown of economies during the past few years have been due to many factors such as the economic crisis, fluctuations in fuel and exchange rates along with terrorist issues. Despite this, the number of travelers and travel revenue have shown increases year on year (Kattiyapornpong and Miller, 2001).

International tourist arrivals and tourism receipts as of 2009 are given in Figure 1 (WTO, 2010). According to the statistics, Europe stands as the most attractive tourist region, while Asia and the Pacific region take second place. 


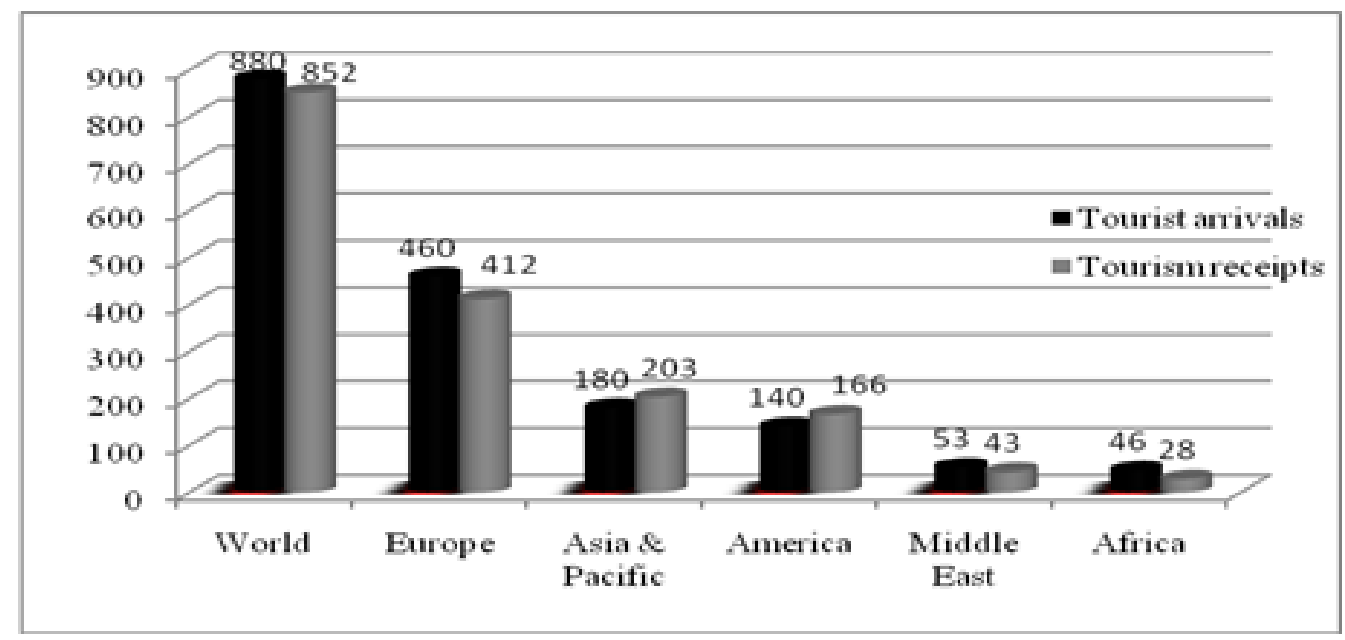

Figure 1: The number of tourists according to the world and their regions ( ${ }^{*}$ million) tourism receipts (*billion \$) (2009)

According to WTO (2010) data, the top three countries to attract tourists are France (74.2 million), the USA (54.9 million) and Spain (52.2 million). Additionally, tourism receipts rank as the USA (94.2 billion \$), Spain (53.2 billion \$) and France (48.7 billion \$).

Other than tourist arrivals and tourism receipts, tourism indicators are formed by different variables across various factors such as occupancy rate, average length of stay, number of enterprises, number of rooms, number of bedrooms, employment, the rate of tourism revenues in Gross Domestic Product (GDP) and the rate of tourism in goods and service exports.

There is a strong relationship between expansion and development of the tourism sector and the organizational performances of hotel enterprises. Whilst the tourism industry is directly influenced by the occupancy rate and sales revenue of hotel enterprises, development within the tourism industry has an indirect influence on the organizational performance of hotel enterprises (Sharpley, 2000; Dritsakis, 2004; Lee and Chang, 2008; Garcia and Raya, 2008; Chen, 2010). In reference to this, Chen and Yang (2010) refer to the multiplier effect of tourism activities using the CGE model, ‘Computable General Equilibrium'.

The number of destination arrivals is an obvious factor in acquiring high tourism receipts, but the average length of stay is also an important factor. In the decision making process of holiday 
purchases, the length of stay is dependent on two variables. These are summarized as individual features and economic features. Individual elements such as age, education level, sex, marital status, family and number of children, are important factors in the decision of holiday term. Likewise, the level of income and cost of the holiday can also be a determinative. This takes into consideration that increases in holiday prices may result in a decrease of people having a fixed income (Alegre and Pou, 2006). In this context, Chang and Liao (2010) highlighted the importance of accurate forecasting regarding future tourism flow when allocating investment that will lead to success in the tourism industry for both public and private sectors.

According to the World Tourism Organization (WTO, 2010), while there is no data to define the contribution of tourism to gross domestic product in the world, this value lies within a vast range and generally fluctuates between $2 \%$ and $12 \%$ (Ashley et al., 2007). Alternatively, in developing economies it can rise up to $40 \%$, whilst in small island economies, up to $70 \%$.

By the application of multivariate statistical methods, this study has aimed to classify and rank 47 countries from every region of the world through the collection and analysis of tourism data throughout the last six years (2004-2009).

\section{METHODOLOGY}

Collection of Data: There are many and various indicators to record tourism activity statistics within any one country. However, it is necessary to have common and obtainable indicators or variables in order to make comparisons between different countries. The data set composed for this study consists of 47 countries from different regions of the world between 2004 and 2009. In this frame, tourism statistics consisting of nine variables are shown in Table 1. The last three variables show the rate of tourism receipts in GDP and the rate of tourist goods and services as total exports.

During the research process, the intention was to obtain tourism indicators from approximately 100 countries. This would consist of different variables extracted from published articles, web sites and other communication techniques. By consideration of the systematic process of this study, according to statistics retained during 2004 to 2009 , nine variables were found to be common and obtainable 
across 47 countries. Subject data was obtained through WTO (2009) and WTO (2010) statistics, by scanning official websites of different countries (related ministries and statistics institutions). Missing data was obtained by establishing contacts through telephone, fax, e-mail etc., to the related offices of national and international institutions.

Table 1: Variables used within the research (tourism indicators), and Countries

\begin{tabular}{|c|c|c|}
\hline Variables & Denominatio & Countries \\
\hline Number of Tourists & tNumber & Australia, \\
\hline visitors) & & Azerbaijan, Belarus, Chile, \\
\hline Tourism Receipts & $\$(U S A)$ & China, Croatia, Cyprus, \\
\hline Number of Rooms & Number & Czech Republic, Egypt, El \\
\hline Number of Bed-Places & Number & Salvador, Estonia, Finland, \\
\hline Occupancy Rate & Percent (\%) & Germany, \\
\hline Average Length of Stay & Nights & Honduras, \\
\hline Gross Domestic Product (GDP) Rate & Percent (\%) & Iceland, Indonesia, Israel, \\
\hline Export of Goods Rate & Percent (\%) & Italy, Jamaica, Jordan, \\
\hline Export of Services Rate & Percent (\%) & Lithuania, \\
\hline & & Macedonia, \\
\hline & & Netherlands, \\
\hline & & Niger, Norway, Panama, \\
\hline & & Paraguay, \\
\hline & & Philippines, \\
\hline & & Portugal, Saudi Arabia, \\
\hline & & Slovakia, Slovenia, Spain, \\
\hline & & Switzerland, \\
\hline & & Tunisia, Turkey, USA \\
\hline
\end{tabular}


Variables used within this study have been produced in different measurement units, thus in different numeric sizes. For this reason, in order to prevent more or less weighting of variables, both raw and standardized data were used.

Statistical Methods: The data obtained was analyzed using the program SPSS 14.01. Additionally, the use of multivariate analyses was applied in order to rank and classify the tourism indicators based on nine variables across 47 countries between 2004 and 2009 (Table 1). By taking the arithmetic mean of tourism data between 2004 and 2009 for each variable, the analysis was fulfilled.

Although the case inspected should be taken as one single entity, analysis with univariate statistical methods may influence the validity and reliability of obtained results (Kramer, 1978). For this reason, where more than two variables were in question, multivariate analyses having various variables, being different but related, are used for each unit by taking all variables into consideration synchronously (Boch and Huang, 1974; Hair et al., 1998).

Multivariate statistical methods of this study were firstly used for non-standardized data, but the same analyses were also applied to standardized data. The reason for this was because of the different measurement units (number, $\$$, day, percentage) and different values of data belonging to each variable. In standardizing the data, values obtained from the subtraction of average values from each value belonging to a variable, were divided into the result obtained by standard deviation value $[(x-\mu) / \sigma]$. In this frame, findings from standardized and non-standardized data were presented together for comparison purposes.

Principal Component Analysis: Principal component analysis was used for ranking of countries in terms of tourism indicators. Principal component analysis is a multivariate statistics technique which is used for data reduction and interpretation. It explains the variant-covariant structure of a particular data set belonging to variables through their linear combination. Upon completion of the analysis, the ' $n$ ' unit and ' $p$ ' variable elements showing a mutual structure dependency are converted into $k(k \leq p)$ new variables, being independent of each other (Johnson and Wichern, 2002). 
The tourism indicators of 47 countries are made up of nine variables, therefore the data matrix is at 9x47 dimensions as shown below:

$$
\mathrm{X}=\left[\begin{array}{cc}
X_{1,1} & X_{1,2} \ldots \ldots X_{1,47} \\
X_{2,1} & X_{2,2} \ldots \ldots X_{2,47} \\
\cdots \ldots \ldots \ldots \ldots \ldots \ldots \ldots . . \\
X_{9,1} & X_{9,2} \ldots \ldots . . X_{9,47}
\end{array}\right]
$$

The matrix lines show the variables whilst the columns show the countries. The results of principal component analysis used within the study shows that there are components (with fewer numbers than those of the variables) that have eigenvalues higher than 1 , which explains a considerable part of the total variance. Thereafter, the principal component load matrix was obtained which gives the weights of variables within principal components. By multiplying the transposition of this matrix $\left(\mathrm{e}^{\mathrm{t}}\right)$ by the above given data matrix, the development index of tourism indicators were developed along with the sorting, according to this index.

Clustering Analysis: Clustering analysis is the calculation of distance or similarity of levels between units or variables. Therefore, the intention of this study was to classify the number of ' $n$ ' units to homogeneous groups and to heterogeneous sub groups respectively (Hawkins et al., 1982; Krzanowski and Lai, 1988; Özdamar, 2004). Clustering analysis is applied to investigate the features of units synchronously instead of separately and is divided into two main categories. These are namely 'hierarchical' and 'non-hierarchical' clustering methods that apply different criteria to the calculation of distance between units. From these, the most common criteria used for hierarchical methods is that of Euclidian distance. The data matrix lines are $i$ and $j$ with the variant number as $p$, therefore the Euclidian distance (d) is calculated as within the equation (eq.1) below (Mardia et al., 1989; Manly, 1994; Özdamar, 2004):

$$
d\left(x_{i}, x_{j}\right)=\left[\sum_{k=1}^{p}\left(x_{i k}-x_{j k}\right)^{2}\right]^{\frac{1}{2}}(1)
$$

Complete Linkage Cluster Analysis from hierarchical clustering methods was applied for the classification of countries discussed within this study in terms of tourism indicators, by using 
similarities and differences. For the distance unit, the Euclidian Distance Unit was used. In light of these values the dendrogram was formed. As a result of the analysis, to define the most probable clustering number (c), dendrograms were inspected. Additional use of the cluster membership codes (scores) which are formed in clustering, this resulted in an increasing clustering number with one consecutively $(c=2,3,4, \ldots)$. Discriminant Analysis was then used for the new data structure and correct classification rates were found.

Multidimensional Scaling Analysis: Multidimensional scaling is used to obtain the projection of units based on distances. These are defined according to ' $p$ ' variables in between ' $n$ ' units in lesser numbered ' $\mathrm{k}$ ' dimensioned $(\mathrm{k}<\mathrm{p})$ space. This produces a graphical explanation of the proximity of units between themselves by evaluating their positions within the Euclidian space (Özdamar, 2004). Likewise, multidimensional scaling analysis was applied to this study to form a multidimensional scaling graph. This was achieved by defining the positions of countries in two-dimensional space according to their distance or proximity levels in terms of tourism indicators, and for comparison to the clustering analysis results. The Euclidian distance model was used within this study and the conformity of configuration distances to the original distances was evaluated by calculating the stress statistics.

\section{RESULTS}

Arithmetic mean and standard error of mean (SEM) values of data belonging to the tourism indicators of 47 countries in scope of this study are presented in Table 2 . This shows that 11.5 million tourists and 13.5 billion dollars of tourism receipts per annum are produced per country in the frame of the extracted data during 2004-2009. The number of rooms per country is around 279 thousand, while the number of beds is almost 568 thousand. The average occupancy rate is 48.83 , with the average length of stay being 3.49. The annual share of tourism receipts in GDP is an average of $4.85 \%$ per country whilst the share of tourist goods from total exports is $22.29 \%$ and the share of services at $44.31 \%$ 
Table 2: Means of 47 countries in terms of tourism indicators

\begin{tabular}{lll}
\hline Variables & \multicolumn{1}{l}{ Means } & \multicolumn{1}{l}{ SEM } \\
\hline Number of Tourists & 11585808.51 & 2646635.98 \\
Tourism Receipts & 13321191.49 & 3294119.46 \\
Number of Rooms & 278639.32 & 102467.72 \\
Number of Bed-Places & 567841.49 & 210547.09 \\
Occupancy Rate & 48.83 & 1.69 \\
Average Length of Stay & 3.49 & 0.34 \\
GDP Rate & 4.85 & 0.69 \\
Export of Goods Rate & 22.29 & 5.54 \\
Export of Services Rate & 44.31 & 3.21 \\
\hline
\end{tabular}

Principal component analysis results used to sort countries in terms of tourism indicators are given in Table 3. The inspection of Eigenvalues shows that two principal components explain the nine variables by $70.123 \%$ of total variance.

Table 3: Eigenvalues of principal component and total variance explained

\begin{tabular}{llll}
\hline \multicolumn{3}{l}{ Component Eigenvalues \% of Variance } & Cumulative \% \\
\hline 1 & 3.853 & 42.814 & 42.814 \\
2 & 2.458 & 27.309 & 70.123 \\
3 & 0.844 & 9.373 & 79.497 \\
4 & 0.702 & 7.799 & 87.295 \\
5 & 0.649 & 7.212 & 94.507 \\
6 & 0.253 & 2.810 & 97.317 \\
7 & 0.197 & 2.185 & 99.502 \\
8 & 0.044 & 0.492 & 99.994 \\
9 & 0.001 & 0.006 & 100.000 \\
\hline
\end{tabular}


The principal component load matrix indicating the weights of variables in principal components is shown in Table 4. The first principal component scores of four variables explain $42.814 \%$ of the total variance. The second principal component score of the last five variables (occupancy rate, average length of stay, GDP rate, export of goods rate, export of services rate) which explains $27.309 \%$ of the total variance, is found to be higher overall. This situation is a result of a higher level of correlation between the first four variables (number of tourists, tourism receipts, number of rooms, number of bedrooms), which are made up of numbers. The correlation between the other five variables (occupancy rate, average length of stay, GDP rate, exports of goods rate, exports of services rate) are made up of rates and averages, so this is an expected result.

Table 4: Principal component scores of variables

\begin{tabular}{lcc}
\hline Variables & \multicolumn{2}{c}{ Component } \\
\cline { 2 - 3 } & $\mathbf{1}$ & $\mathbf{2}$ \\
\hline Number of Tourists & 0.211 & -0.026 \\
Tourism Receipts & 0.249 & -0.017 \\
Number of Rooms & 0.250 & -0.006 \\
Number of Bed-Places & 0.249 & -0.003 \\
Occupancy Rate & 0.083 & 0.214 \\
Average Length of Stay & 0.132 & 0.220 \\
GDP Rate & -0.059 & 0.344 \\
Export of Goods Rate & -0.027 & 0.335 \\
Export of Services Rate & -0.013 & 0.284
\end{tabular}

The Development index in terms of tourism indicators was formed by multiplying the transpose $\left(\mathrm{e}^{\mathrm{t}}\right)$ of the principal component load matrix with non-standardized and standardized data matrices. The sorting according to this index is presented in Table 5 indicates the sorting of 47 countries in terms of tourism indicators and shows that the USA, France, Spain, China, Italy, Germany, Turkey, Austria, Mexico and Australia take the first 10 places for non-standardized data. The USA, Egypt, Jamaica, 
Cyprus, El Salvador, Morocco, Tunisia, Niger, Croatia and Jordan take the first 10 places for standardized data. The sorting for non-standardized data remains parallel with the WTO (2009-2010) evaluations.

Within the standardized data, the number of tourists, tourism receipts, number of rooms and number of bedrooms are made up of larger numbers. The influence or weight of the variables made up of small numbers (occupancy rate, average length of stay, GDP rate, export of goods rate, export of services rate) remained very little. Countries with a larger population, economy and area took first places in the sorting. Therefore, the influence of all variables in standardized data through sorting was normalized and real sorting of countries according to tourism indicators was obtained (Table 5). Scientific subject researchers and organizations such as the WTO and WTTC (World Travel and Tourism Council) sort or classify by taking either one variable or no standardization for variables managed together. Boch and Huang (1974), Mardia et al (1989), Hair et al (1998) and Johnson and Wichern (2002) emphasize that variables used in sorting and classification of units should be handled synchronously. Data sets with very different sizes and different measurement units (number, time, rate etc.,), shows that it is absolutely necessary to apply standardization to prevent more or less weighting.

Table 5: The sorting of countries according to tourism indicators

\begin{tabular}{|c|c|c|c|c|c|}
\hline \multicolumn{3}{|c|}{ Column 1: non-standardized data } & \multicolumn{3}{|c|}{ Column 2: standardized data } \\
\hline Sort & Index & Countries & Sort & Index & Countries \\
\hline 1 & 41433318.05 & USA & 1 & 0.5877922 & USA \\
\hline 2 & 30408965.95 & France & 2 & 0.5044200 & Egypt \\
\hline 3 & 26599490.53 & Spain & 3 & 0.4906818 & Jamaica \\
\hline 4 & 20805705.48 & China & 4 & 0.3661092 & Cyprus \\
\hline 5 & 19589245.26 & Italy & 5 & 0.2960378 & El Salvador \\
\hline 6 & 16041737.84 & Germany & 6 & 0.2703236 & Morocco \\
\hline 7 & 9109627.74 & Turkey & 7 & 0.2575445 & Tunisia \\
\hline 8 & 9020900.46 & Austria & 8 & 0.2377803 & Niger \\
\hline 9 & 7668149.93 & Mexico & 9 & 0.2227973 & Croatia \\
\hline 10 & 7448962.49 & Australia & 10 & 0.1064455 & Jordan \\
\hline 11 & 6738052.64 & Netherlands & 11 & 0.0981646 & Albania \\
\hline
\end{tabular}




\begin{tabular}{|c|c|c|c|c|c|}
\hline 12 & 5558711.94 & Poland & 12 & 0.0706142 & Honduras \\
\hline 13 & 5376397.32 & Portugal & 13 & 0.0238244 & Panama \\
\hline 14 & 5086361.78 & Switzerland & 14 & 0.0000313 & Mexico \\
\hline 15 & 4504116.83 & Egypt & 15 & -0.0003631 & Spain \\
\hline 16 & 4006953.37 & Croatia & 16 & -0.0140473 & Philippines \\
\hline 17 & 3689435.94 & Saudi Arabia & 17 & -0.0232544 & Austria \\
\hline 18 & 3353530.10 & Morocco & 18 & -0.0240727 & Portugal \\
\hline 19 & 3065464.67 & Czech Republic & 19 & -0.0305252 & Turkey \\
\hline 20 & 2976946.34 & Hungary & 20 & -0.0352245 & Azerbaijan \\
\hline 21 & 2579396.42 & Indonesia & 21 & -0.0356321 & Slovenia \\
\hline 22 & 2123495.78 & Tunisia & 22 & -0.0565814 & Australia \\
\hline 23 & 2016047.41 & Norway & 23 & -0.0696463 & Italy \\
\hline 24 & 1877188.76 & Philippines & 24 & -0.0819755 & China \\
\hline 25 & 1597934.07 & Finland & 25 & -0.0867125 & Hungary \\
\hline 26 & 1291392.12 & Jordan & 26 & -0.0883900 & France \\
\hline 27 & 1287760.67 & Israel & 27 & -0.0889433 & Czech Republic \\
\hline 28 & 1201910.10 & Cyprus & 28 & -0.0922125 & Slovakia \\
\hline 29 & 1018570.97 & Chile & 29 & -0.0937074 & Estonia \\
\hline 30 & 982280.58 & Peru & 30 & -0.0954821 & Belarus \\
\hline 31 & 894829.31 & Slovenia & 31 & -0.1018581 & Israel \\
\hline 32 & 894457.72 & Slovakia & 32 & -0.1019174 & Macedonia \\
\hline 33 & 829579.95 & Jamaica & 33 & -0.1047920 & Saudi Arabia \\
\hline 34 & 696425.65 & Estonia & 34 & -0.1189230 & Switzerland \\
\hline 35 & 633490.78 & Panama & 35 & -0.1224283 & Iceland \\
\hline 36 & 560273.34 & Lithuania & 36 & -0.1376602 & Poland \\
\hline 37 & 522030.54 & El Salvador & 37 & -0.1406978 & Lithuania \\
\hline 38 & 518307.72 & Latvia & 38 & -0.1419514 & Paraguay \\
\hline 39 & 456777.90 & Albania & 39 & -0.1439823 & Indonesia \\
\hline 40 & 407993.69 & Iceland & 40 & -0.1526428 & Latvia \\
\hline 41 & 329936.73 & Azerbaijan & 41 & -0.1621162 & Netherlands \\
\hline 42 & 296457.67 & Honduras & 42 & -0.1625491 & Finland \\
\hline 43 & 169974.95 & Swaziland & 43 & -0.1736251 & Germany \\
\hline 44 & 140061.01 & Belarus & 44 & -0.1793575 & Chile \\
\hline 45 & 109536.75 & Paraguay & 45 & -0.2098398 & Norway \\
\hline 46 & 99461.37 & Macedonia & 46 & -0.2140195 & Peru \\
\hline 47 & 19743.45 & Niger & 47 & -0.2474357 & Swaziland \\
\hline
\end{tabular}


The inspection of indices in Table 5 shows that the USA takes first place in both sortings according to tourism statistics and ranking of countries. It takes first place in column 1 and changes in column 2 as they go to lower rankings. For example, France in second place in column 1, goes down to 26thplace, the third, Spain, goes to 15 th place, the fourth, China, goes to 24th place, the fifth, Italy, goes to 23 rd place and the sixth, Germany, falls back to 43rd place. On the other hand, Egypt, being 15th place in column 1 rises to second place and the $33^{\text {rd }}$ in column 2 , whilst Jamaica rises to third place. This situation is a result of the lower positioning of the GDP rate, export of goods rate and export of services rate between 2004 and 2009. It applies to countries which take first place in column 1 rather than those countries that take first place in column 2.

Findings relating to classification of countries according to tourism indicators in terms of similarities and/or differences by Complete Linkage Cluster Analysis are presented in Table 6, Table 7 and Table 8; dendrograms are presented in Figure 2 and Figure 3.

Table 6: Clustering of countries according to tourism indicators by complete linkage clustering method (non-standardized data)

c Countries

Cluster 1: USA, Germany, China, Italy, France, Spain; Cluster 2: Australia, Mexico, Turkey, Austria, Switzerland, Netherlands, Poland, Portugal, Saudi Arabia, Egypt, Croatia, Hungary, Morocco, Czech Republic, Tunisia, Indonesia, 100.

2 Philippines, Norway, Azerbaijan, Swaziland, Honduras, Belarus, Niger, Macedonia, Paraguay, Panama, Estonia, Latvia, 0

Lithuania, El Salvador, Albania, Iceland, Jordan, Finland, Israel, Cyprus, Chile, Peru, Jamaica, Slovenia, Slovakia

Cluster 1: USA; Cluster 2: Germany, China, Italy, France, Spain; Cluster 3: Australia, Mexico, Turkey, Austria, Switzerland, Netherlands, Poland, Portugal, Saudi Arabia, Egypt, Croatia, Hungary, Morocco, Czech Republic, Tunisia,

3 Indonesia, Philippines, Norway, Azerbaijan, Swaziland, Honduras, Belarus, Niger, Macedonia, Paraguay, Panama,

Estonia, Latvia, Lithuania, El Salvador, Albania, Iceland, Jordan, Finland, Israel, Cyprus, Chile, Peru, Jamaica, Slovenia,

Slovakia

Cluster 1: USA; Cluster 2: Germany, China, Italy; Cluster 3: France, Spain; Cluster 4: Australia, Mexico, Turkey, Austria, Switzerland, Netherlands, Poland, Portugal, Saudi Arabia, Egypt, Croatia, Hungary, Morocco, Czech Republic, Tunisia,

4 Indonesia, Philippines, Norway, Azerbaijan, Swaziland, Honduras, Belarus, Niger, Macedonia, Paraguay, Panama,

Estonia, Latvia, Lithuania, El Salvador, Albania, Iceland, Jordan, Finland, Israel, Cyprus, Chile, Peru, Jamaica, Slovenia,

Slovakia 


\section{Cluster 1: USA; Cluster 2: Germany; Cluster 3: China, Italy; Cluster 4: France}

Cluster 5: Spain; Cluster 6: Australia, Mexico, Turkey, Austria; Cluster 7: Switzerland, Netherlands, Poland, Portugal,

8 Saudi Arabia, Egypt, Croatia, Hungary, Morocco, Czech Republic; Cluster 8: Tunisia, Indonesia, Philippines, Norway,

Azerbaijan, Swaziland, Honduras, Belarus, Niger, Macedonia, Paraguay, Panama, Estonia, Latvia, Lithuania, El Salvador, Albania, Iceland, Jordan, Finland, Israel, Cyprus, Chile, Peru, Jamaica, Slovenia, Slovakia

Cluster 1: USA; Cluster 2: Germany; Cluster 3: China, Italy; Cluster 4: France

Cluster 5: Spain; Cluster 6: Australia; Cluster 7: Mexico, Turkey, Austria; Cluster 8: Switzerland, Netherlands, Poland,

9 Portugal, Saudi Arabia, Egypt, Croatia, Hungary, Morocco, Czech Republic; Cluster 9: Tunisia, Indonesia, Philippines, 93.6 Norway, Azerbaijan, Swaziland, Honduras, Belarus, Niger, Macedonia, Paraguay, Panama, Estonia, Latvia, Lithuania, El Salvador, Albania, Iceland, Jordan, Finland, Israel, Cyprus, Chile, Peru, Jamaica, Slovenia, Slovakia

Cluster 1: USA; Cluster 2: Germany; Cluster 3: China, Italy; Cluster 4: France

Cluster 5: Spain; Cluster 6: Australia; Cluster 7: Mexico, Turkey, Austria; Cluster 8: Switzerland, Netherlands, Poland,

Portugal; Cluster 9: Saudi Arabia, Egypt, Croatia, Hungary, Morocco, Czech Republic; Cluster 10: Tunisia, Indonesia, 91.5

Philippines, Norway, Azerbaijan, Swaziland, Honduras, Belarus, Niger, Macedonia, Paraguay, Panama, Estonia, Latvia,

Lithuania, El Salvador, Albania, Iceland, Jordan, Finland, Israel, Cyprus, Chile, Peru, Jamaica, Slovenia, Slovakia

c: Number of Cluster "Correctly Classified Percentages

At the end of the analysis, dendrograms were inspected. These reflections of homogeneity formed clusters within themselves and heterogeneity between themselves (Fig. 2-3), showing that for both non-standardized and standardized data, countries are divided into two principal groups according to tourism indicators. Non-standardized data applied to the USA, Germany, China, Italy, France and 
Spain in the first group, while in other countries it appeared in the second group. When the number of clusters is 3, Germany, China, Italy, France and Spain leave the first group and move to the second group. With four clusters, France and Spain leave the second cluster and go to another group (Table $6)$.

Regarding standardized data, the USA, Egypt, Niger and El Salvador are indicated in the first group, while other countries occur in the second group. The increase of clusters to three shows that Jamaica, Cyprus, Morocco, Tunisia, Croatia and Jordan separate from other countries and make up a different cluster. For four clusters, the USA is placed in a separate group (Table 7).

Table 7: Clustering of countries according to tourism indicators by complete linkage clustering method (standardized data)

\begin{tabular}{|c|c|c|}
\hline c & Countries & $\%^{*}$ \\
\hline 2 & $\begin{array}{l}\text { Cluster 1: USA, Egypt, Niger, El Salvador; Cluster 2: Jamaica, Cyprus, Morocco, Tunisia, Croatia, Jordan, Macedonia, } \\
\text { Honduras, Mexico, Azerbaijan, Spain, Turkey, Austria, Portugal, Slovenia, Italy, Slovakia, Panama, Albania, Swaziland, } \\
\text { Peru, Philippines, France, Australia, China, Belarus, Paraguay, Israel, Czech Republic, Switzerland, Hungary, Estonia, } \\
\text { Iceland, Saudi Arabia, Indonesia, Norway, Finland, Netherlands, Poland, Lithuania, Latvia, Germany, Chile }\end{array}$ & 100. \\
\hline 3 & $\begin{array}{l}\text { Cluster 1: USA, Egypt, Niger, El Salvador; Cluster 2: Jamaica, Cyprus, Morocco, Tunisia, Croatia, Jordan; Cluster 3: } \\
\text { Macedonia, Honduras, Mexico, Azerbaijan, Spain, Turkey, Austria, Portugal, Slovenia, Italy, Slovakia, Panama, Albania, } \\
\text { Swaziland, Peru, Philippines, France, Australia, China, Belarus, Paraguay, Israel, Czech Republic, Switzerland, Hungary, } \\
\text { Estonia, Iceland, Saudi Arabia, Indonesia, Norway, Finland, Netherlands, Poland, Lithuania, Latvia, Germany, Chile }\end{array}$ & 97.9 \\
\hline 4 & $\begin{array}{l}\text { Cluster 1: USA; Cluster 2: Egypt, Niger, El Salvador; Cluster 3: Jamaica, Cyprus, Morocco, Tunisia, Croatia, Jordan; } \\
\text { Cluster 4: Macedonia, Honduras, Mexico, Azerbaijan, Spain, Turkey, Austria, Portugal, Slovenia, Italy, Slovakia, } \\
\text { Panama, Albania, Swaziland, Peru, Philippines, France, Australia, China, Belarus, Paraguay, Israel, Czech Republic, } \\
\text { Switzerland, Hungary, Estonia, Iceland, Saudi Arabia, Indonesia, Norway, Finland, Netherlands, Poland, Lithuania, } \\
\text { Latvia, Germany, Chile }\end{array}$ & 97.9 \\
\hline 5 & $\begin{array}{l}\text { Cluster 1: USA; Cluster 2: Egypt, Niger, El Salvador; Cluster 3: Jamaica, Cyprus, Morocco, Tunisia; Cluster 4: Croatia, } \\
\text { Jordan; Cluster 5: Macedonia, Honduras, Mexico, Azerbaijan, Spain, Turkey, Austria, Portugal, Slovenia, Italy, Slovakia, } \\
\text { Panama, Albania, Swaziland, Peru, Philippines, France, Australia, China, Belarus, Paraguay, Israel, Czech Republic, } \\
\text { Switzerland, Hungary, Estonia, Iceland, Saudi Arabia, Indonesia, Norway, Finland, Netherlands, Poland, Lithuania, } \\
\text { Latvia, Germany, Chile }\end{array}$ & 95.7 \\
\hline 6 & $\begin{array}{l}\text { Cluster 1: USA; Cluster 2: Egypt, Niger, El Salvador; Cluster 3: Jamaica, Cyprus, Morocco, Tunisia; Cluster 4: Croatia, } \\
\text { Jordan; Cluster 5: Macedonia, Honduras, Mexico, Azerbaijan, Spain, Turkey, Austria, Portugal, Slovenia, Italy, Slovakia; }\end{array}$ & 95.7 \\
\hline
\end{tabular}




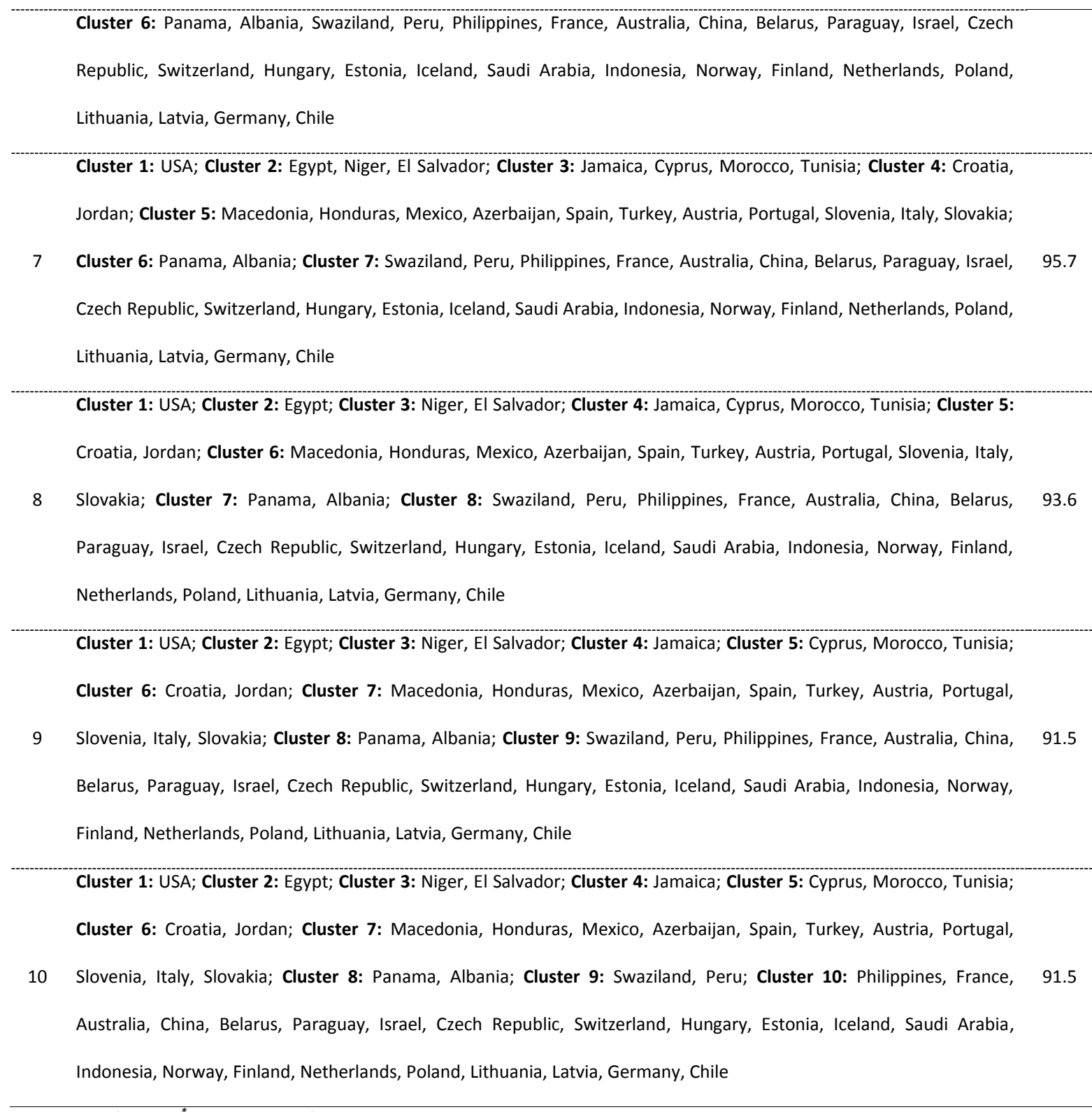
c: Number of Cluster ${ }^{*}$ Correctly Classified Percentages

The result of Discriminant Analysis, applied by using the cluster membership codes (scores) obtained for each number of clusters $(c=2,3,4, \ldots)$, show that the best clustering number for both data sets (non-standardized and standardized) is two. Therefore, the cluster means for both clusters in Table 8 shows that non-standardized data relating to other variables apart from the GDP Rate, Exports of Goods Rate and Exports of Services Rate, the mean of the first cluster is found to be higher. This is made up of six countries, the USA, Germany, China, Italy, France and Spain. Regarding standardized data, only the GDP rate is higher in the second group. 
Table 8: Cluster means obtained by complete linkage clustering method

\begin{tabular}{|c|c|c|c|c|}
\hline \multirow{3}{*}{ Variables } & \multicolumn{2}{|c|}{ Non-standardized data } & \multicolumn{2}{|c|}{ Standardized data } \\
\hline & Cluster $1(n=6)$ & Cluster $2(n=41)$ & Cluster $1(n=4)$ & Cluster $2(n=43)$ \\
\hline & Mean & Mean & Mean & Mean \\
\hline Number of Tourists & 53231166.67 & 5491365.85 & 16995750.00 & 11082558.14 \\
\hline Tourism Receipts (\$) & 63683000.00 & 5951170.73 & 32687250.00 & 11519697.67 \\
\hline Number of Rooms & 1573938.00 & 89083.41 & 1168904.50 & 195823.95 \\
\hline Number of Bed-Places & 3166990.00 & 187478.29 & 2427879.50 & 394814.70 \\
\hline Occupancy Rate (\%) & 53.43 & 48.16 & 57.70 & 48.01 \\
\hline Average Length of Stay (nights) & 4.68 & 3.35 & 9.57 & 2.92 \\
\hline GDP Rate (\%) & 2.17 & 5.25 & 3.95 & 4.93 \\
\hline Export of Goods Rate (\%) & 10.95 & 23.95 & 22.87 & 22.23 \\
\hline Export of Services Rate (\%) & 36.73 & 45.42 & 50.95 & 43.69 \\
\hline
\end{tabular}

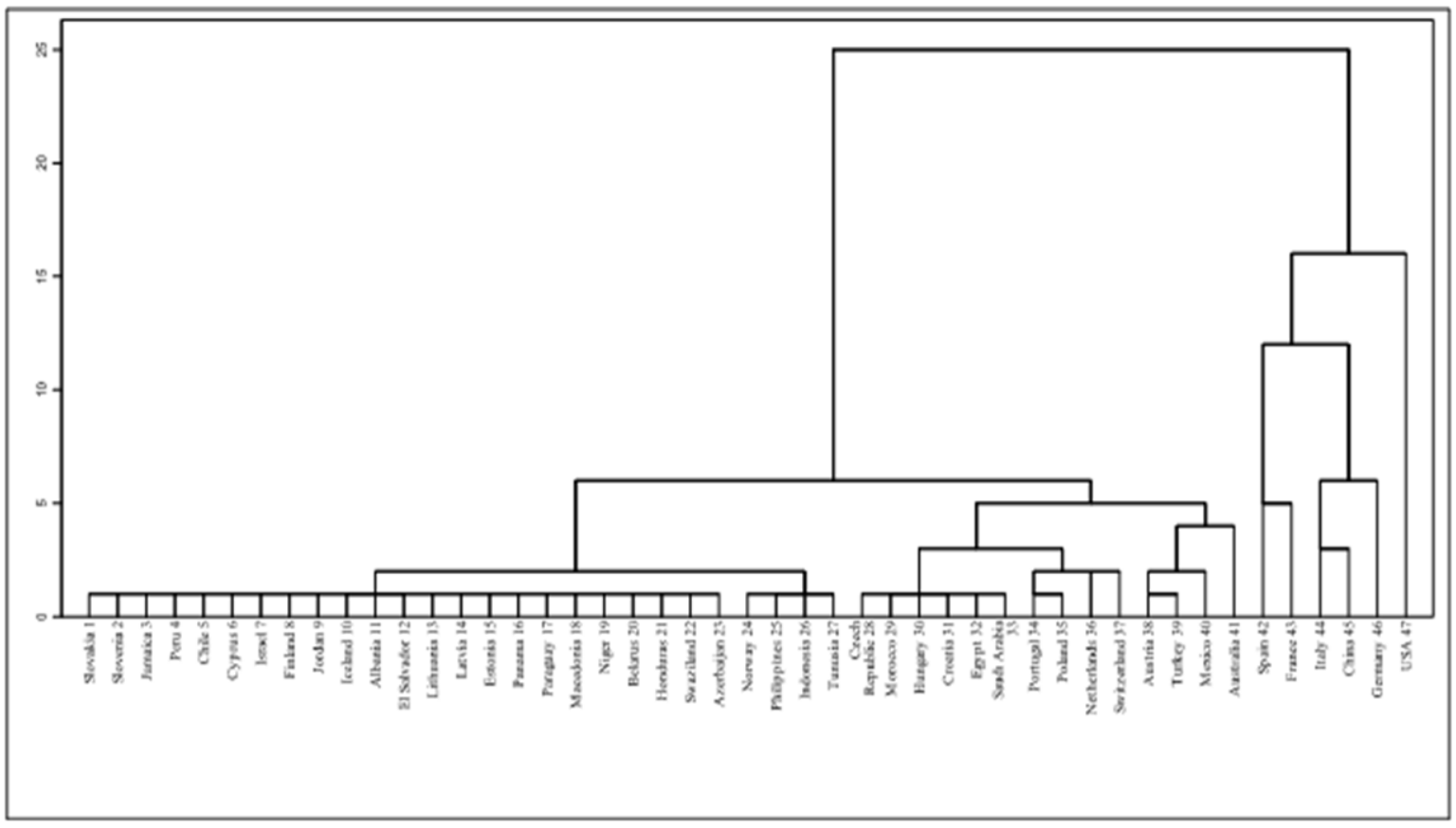

Figure 2: Dendrogram related to clustering of countries (for non-standardized data) 


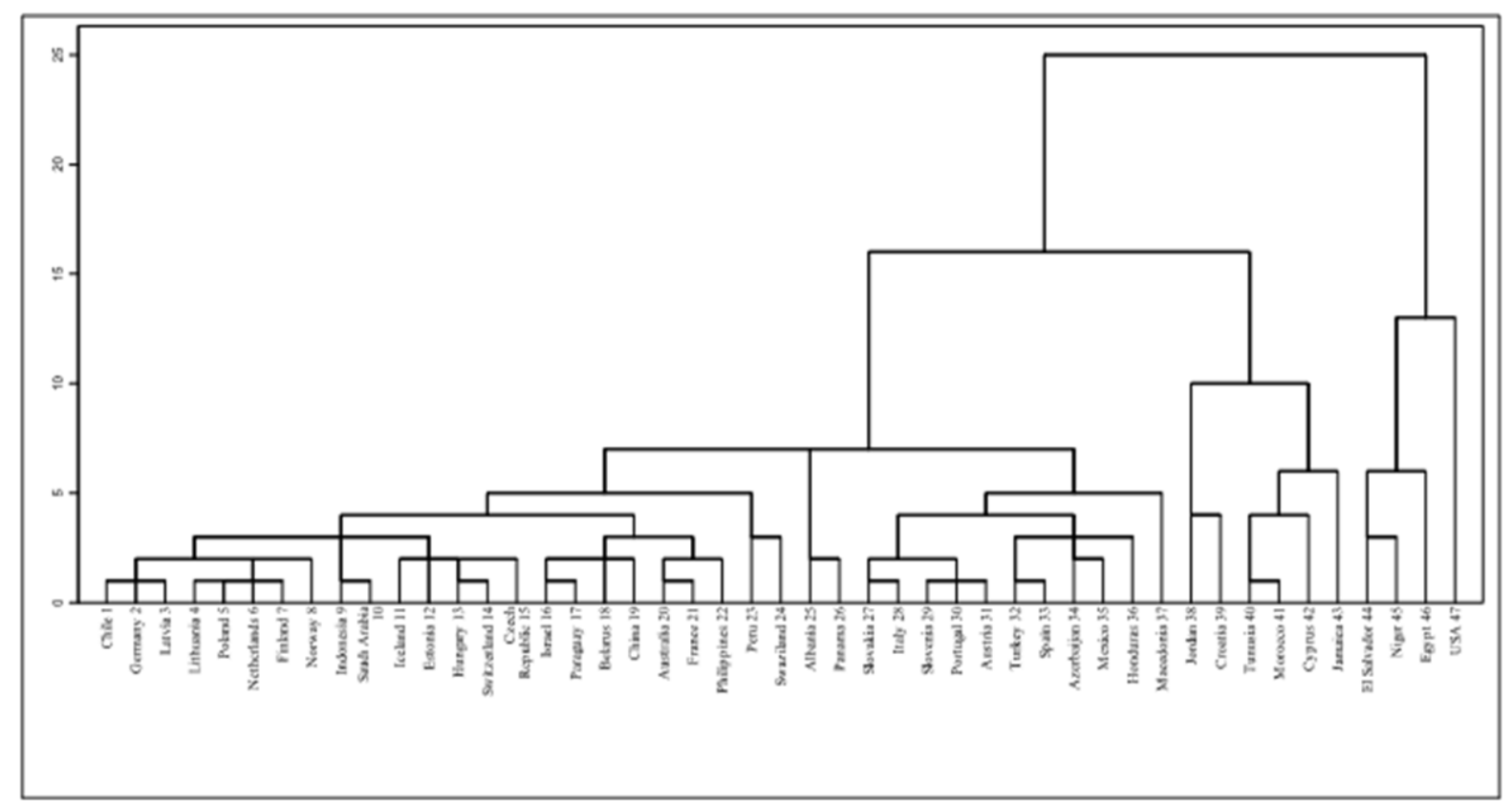

Figure 3: Dendrogram related to clustering of countries (for standardized data)

The graphics obtained through multidimensional scaling analysis are used for defining the positions of countries in two-dimensional space. This is according to the distance or proximity levels in terms of tourism indicators which are shown in Figures 4 and 5. From the two-dimensional scaling graphs, it is determined that countries show clustering similar to that of the sorting obtained from clustering analysis for both data sets (non-standardized and standardized). On the other hand, stress statistics were calculated at 0.034 and this value showed a perfect match between configuration distances and original distances.

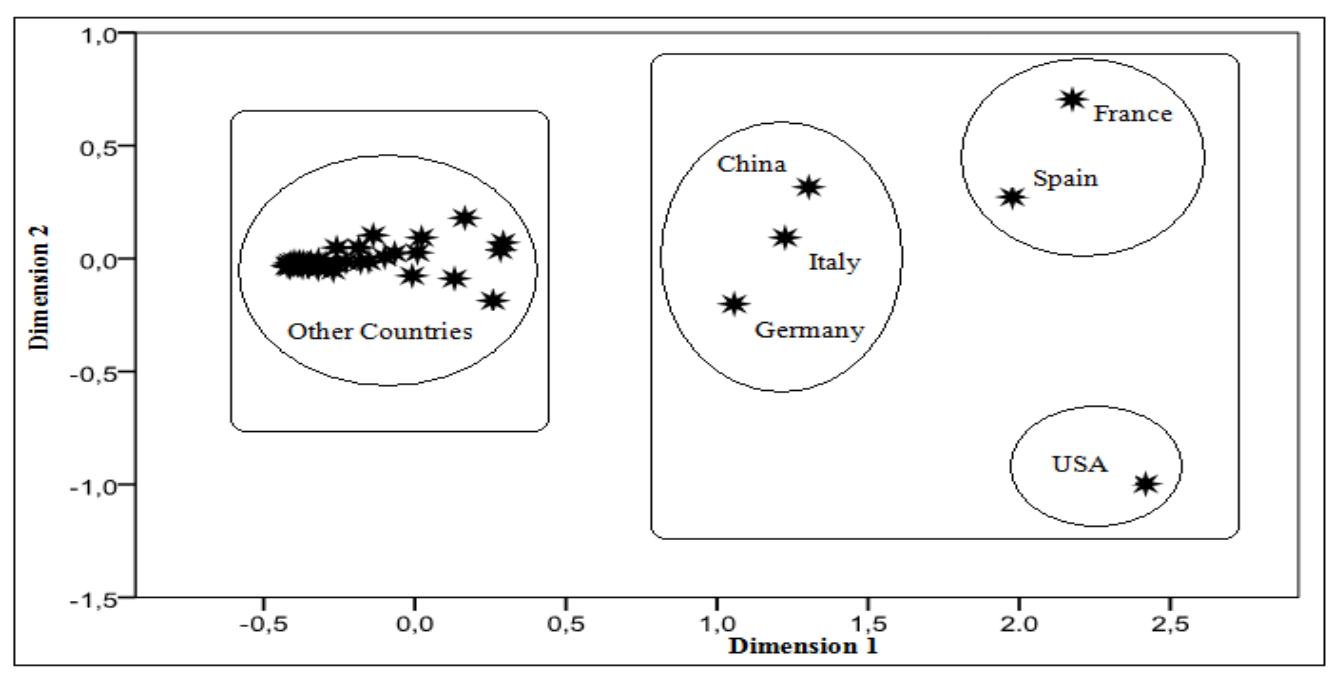

Figure 4: Two-dimensional multidimensional scaling graph according to non-standardized data 


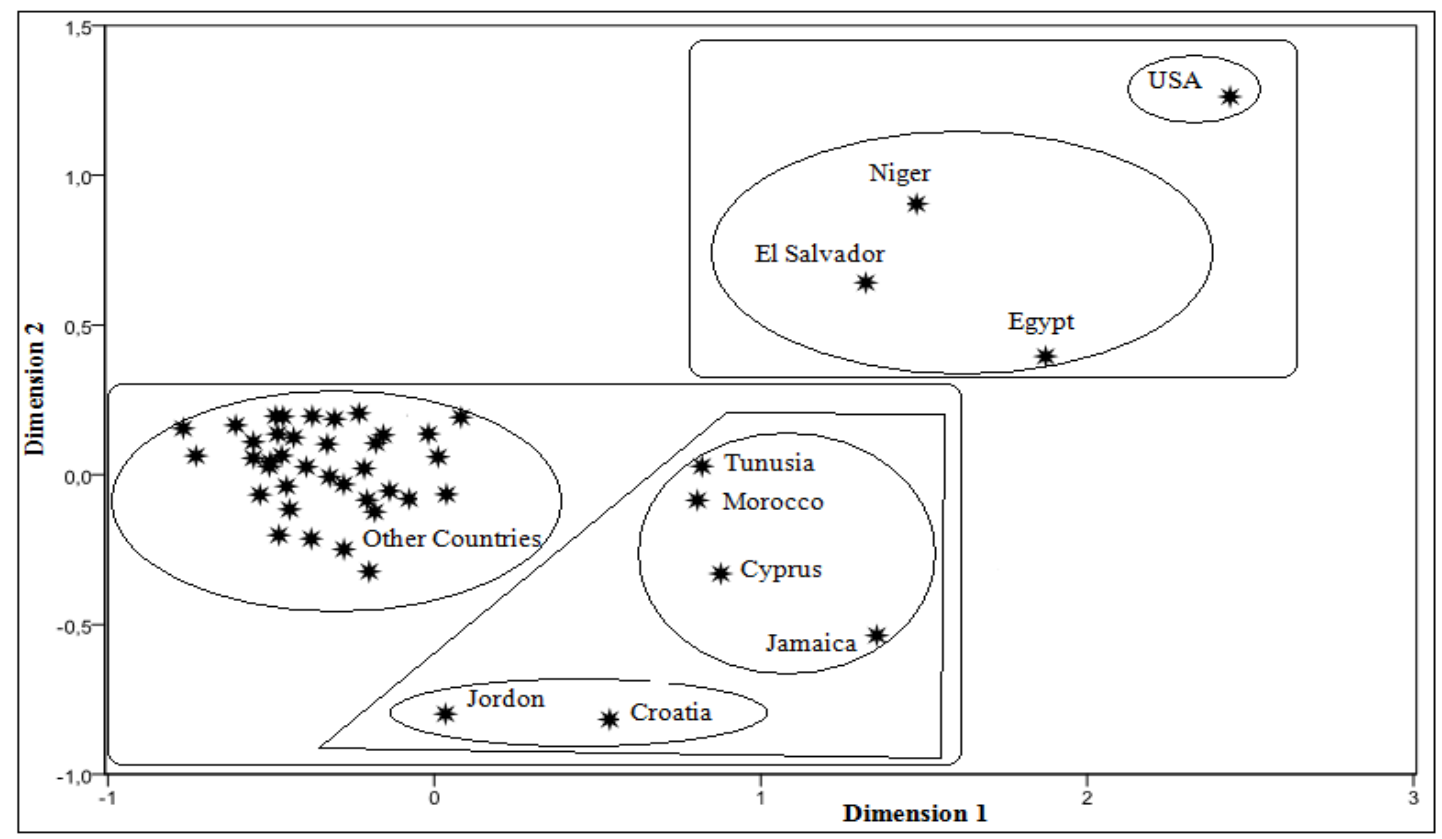

Figure 5: Two-dimensional multidimensional scaling graph according to standardized data

\section{CONCLUSION}

The intention of this study was to sort and classify 47 countries from different regions of the world according to tourism indicators defined by nine variables between 2004 and 2009. For comparison purposes, standardized data was applied as well as non-standardized data. Multivariate analyses were applied for the synchronous evaluation of variables.

The results indicated that the nine variables linked to the tourism indicators of 47 countries were explained by two principal components, thereafter explaining $70.123 \%$ of total variance. In terms of tourism indicators the development index of countries is obtained by using the principal component load matrix. This provided the weights of nine variables across the two principal components. The USA, France, Spain, China and Italy take first five places for non-standardized data. This ranking changes for standardized data to the USA, Egypt, Jamaica, Cyprus and El Salvador.

Within this study, results of the clustering analysis were applied to sort countries according to the distance or proximity levels in terms of tourism indicators. The results of multi-dimensional scaling analysis was applied to locate the positions in space and showed similar results. Both nonstandardized and standardized data indicated that countries principally cluster in two groups (more 
homogeneous within themselves and more heterogeneous between them). In relation to nonstandardized data, the USA, Germany, China, Italy, France and Spain are positioned in the first group. This group contains the average values of numbers of tourists, tourism receipts, number of rooms, number of bedrooms; occupancy rate and average length of stay are higher than other countries. Standardized data within the first group consisted of the USA, Egypt, Niger and El Salvador, whereby the averages of indicators (other than the GDP rate) were higher than other countries.

Tourism statistic valuations produced by such institutions as WTO and WTTC, take variables into consideration one by one (instead of synchronously); therefore unity of the subject related to the comparison of countries could not be reflected correctly. On the other hand, from the evaluations made, the important factor of country size is not taken into consideration whereby only tourism receipts and number of tourists are considered. Therefore, the evaluation of a country in terms of tourism activities or indicators, along with comparison to other countries, should take the population, economic and area size into consideration. For example, while 50 million tourists per year may not mean much to a country with a large population, economic volume and area, another smaller country would consider five million tourists as very important. Thus evaluations made by taking only relative numbers into consideration, may be incorrect by stating that a large country is ahead in tourism statistics or that the small country is behind. In addition to tourism receipts and tourist numbers, variables that reflect the averages and rates of important parameters of tourism indicators should be taken into consideration. To confirm, these indicators are: occupancy rate, average length of stay, GDP rate, export of goods rate and the export of services rate. Therefore, by standardizing these values, synchronous evaluations with multivariate statistics should be accepted as the correct approach. Through application of the standardization process, more or less weighting of variables in different sizes and different measurement units, can be prevented. To this end, true classification and sorting of units can be realized. 


\section{REFERENCES}

Alegre, J. \& Llorenc, P. (2006). The Length of Stay in the Demand for Tourism, Tourism Management, (27), 1343-1355.

Ashley, C., De Brine, P., Lehr, A. \& Wilde, H. (2007). The Role of the Tourism Sector in Expanding Economic Opportunity, Economic Opportunity Series. Harvard University, Cambridge.

Belloumi, M. (2010). The Relationship between Tourism Receipts, Real Effective Exchange Rate and Economic Growth in Tunisia. International Journal of Tourism Research, 12, (5), 550-560.

Boch, B.W. \& Huang, C. J. (1974). Multivariate Statistical Methods for Business and Economics. New York: Prentice Hall Inc.

Chang, Y., \& Liao, M. (2010). A Seasonal ARIMA Model of Tourism Forecasting: The Case of Taiwan. Asia Pacific Journal of Tourism Research, 15(2), 215-221.

Chen, C. F., \& Chiou-Wei, S. Z. (2009). Tourism Expansion, Tourism Uncertainty and Economic Growth: New Evidence from Taiwan and Korea, Tourism Management, 30, (6), 812-818.

Chen, M. H. (2010). The Economy Tourism Growth and Corporate Performance in the Taiwanese Hotel Industry, Tourism Management, (31), 665-675.

Chen, K., \& Yang, H. (2010). Appraising the Economic Impact of the "Opening up to Mainland Chinese Tourist Arrivals" Policy on Taiwan with a Tourism-CGE Model. Asia Pacific Journal of Tourism Research, 15(2), 155-175.

Dritsakis, N. (2004). Tourism as a Long-Run Economic Growth Factor: An Empirical Investigation for Greece Using a Causality Analysis. Tourism Economics, 10, (3), 305-316.

Dwyer, L., \& Forsyth, P. (1997). Measuring the Benefits and Yield from Foreign Tourism. International Journal of Social Economics, 24, (1-3), 223-236.

Erdmann, G. (1997). The Impact of Tourism on Coastal Areas. GeoJournal, 42, 1), 39-54.

Esther, M. G., \& Josep, M. R. (2008). Length of Stay for Low-Cost Tourism. Tourism Management, 29, (6), 1064-1075. 
Hair, J. F., Anderson, R. E., Tatham, R. L., \& Black, W. C. (1998). Multivariate Data Analysis. New Jersey: Prentice Hall.

Halseth, G., \& Meiklejohn, C. (2009). Indicators of Small Town Tourism Development Potential: The Case of Fouriesburg, South Africa. Urban Forum, 20, (3), 293-317.

Hawkins, D. M., Muller, M. W. \& Krooden, A. T. (1982). Topics in Applied. Multivariate Analysis. London: Cambridge Üniversity Press.

Hodur, N. M., \& Leistritz, F. L. (2007). Estimating the Economic Impact of Event Tourism, Journal of Convention \& Event Tourism, 8, (4), 63-79.

İçöz, O., \& Kozak, M. (2002), Turizm Ekonomisi, Turhan Kitabevi, 2.Baskı, Ankara.

Johnson, R. A., \& Wichern, D. W. (2002). Applied Multivariate Statistical Analysis. 5nd Ed. New Jersey: Prentice Hall International Inc.

Kar, M., Zorkirişçi, E. \& Yıldıım, M. (2004). Turizmin Ekonomiye Katkısı Üzerine Ampirik Bir Değerlendirme. Akdeniz Üniversitesi, i.i.B.F. Dergisi, (8), 87-112.

Kattiyapornpong, U., \& Miller K. E. (2011). Social Structure and Psychographic Explanations of Destination Preference of Australians'Travel to South-East Asia. Asia Pacific Journal of Tourism Research, 16(1), 39-56.

Kramer, C. Y. (1978). An Overview of Multivariate Analysis. Journal of Dairy Science, (61), 848-854.

Krzanowski, W. J. \& Lai, Y. T. (1988). A Criterion for Determining the Number of Groups in a Data Set Using Sum-of Squares Clustering. Biometrics, (14), 22-34.

Lee, C. C., \& Chang, C. P. (2008), Tourism Development and Economic Growth: A Closer Look at Panels. Tourism Management, 29, (1), 180-192.

Manly, B. F. J. (1994), Multivariate Statistical Methods. New York: Chapman Hall.

Mardia, K. V., Kent, J. T. and Bibby, J. M. (1989). Multivariate Analysis. 7th Ed. London: Academic Press.

Olalı, H. (1990). Turizm Politikası ve Planlaması, i.ü. İşletme Fakültesi Yayınları, İstanbul. 
Özdamar, K. (2004). Paket Programlar ile Istatistiksel Veri Analizi (Çok Değişkenli Analizler). Kaan Kitabevi, Eskişehir.

Raina, A. K., \& Agarwal, S. K. (2004). The Esence of Tourism Development Dynamics, Philosophy and Strategies, Sarup \& Suns, New Delhi, India.

Rızaoğlu, B. (2004). Turizmde Tanıtma, Detay Yayıncılık, 3.Baskı, Ankara.

Rosentraub, M. S., \& Joo, M. (2009). Tourism and Economic Development: Which Investments Produce Gains for Regions. Tourism Management, 30, (5), 759-770.

Scheyvens, R., \& Momsen, J. H. (2008). Tourism and Poverty Reduction: Issues for Small Island States, Tourism Geographies, 10, (1), 22-41.

Schubert, S. F., Brida J. G., \& Risso W.A., (2011). The Impacts of International Tourism Demand on Economic Growth of Small Economies Dependent on Tourism. Tourism Management, 32, (2), 377-385.

Sharpley, R. (2000). The Influence of the Accommodation Sector on Tourism Development: Lesson from Cyprus. Hospitality Management, (19), 275-293.

Torres, R. M., \& Momsen, J. H. (2004). Challenges and Potential for Linking Tourism and Agriculture to Achieve Pro-Poor Tourism Objectives, Progress in Development Studies, (4), 294-318.

WTO (2001). UNWTO Tourism 2020 Vision, http://www.unwto.org/facts/eng/ vision.htm (Erişim Tarihi: 12.11.2010).

WTO (2009). Compendium of Tourism Statistics-Data 2003-2007, World Tourism Organization (UNWTO), Madrid.

WTO (2010). UNWTO World Tourism Barometer. Interim Update April 2010, www.unwto.org (Erişim Tarihi: 12.11.2010).

Yang, C. H., Lin, H.L., \& Han, C. C. (2010). Analysis of International Tourist Arrivals in China: The Role of World Heritage Sites, Tourism Management, 31, (6), 827-837. 